\title{
Expression of VGF mRNA in developing neuroendocrine and endocrine tissues
}

\author{
S E Snyder ${ }^{1}$, B Peng ${ }^{3}$, J E Pintar ${ }^{3}$ and S R J Salton ${ }^{1,2}$ \\ ${ }^{1}$ Fishberg Research Center for Neurobiology, Mount Sinai School of Medicine, New York, New York 10029, USA \\ ${ }^{2}$ Department of Geriatrics, Mount Sinai School of Medicine, New York, New York 10029, USA \\ ${ }^{3}$ Department of Neuroscience and Cell Biology, University of Medicine and Dentistry of New Jersey, Piscataway, New Jersey 08854, USA \\ (Requests for offprints should be addressed to S R J Salton, Fishberg Research Center for Neurobiology, Box 1065, Mount Sinai School of Medicine, \\ One Gustave L Levy Place, New York, NY 10029-6945, USA; Email: stephen.salton@mssm.edu) \\ (S E Snyder is currently at Department of Pediatrics, Division of Child Neurology, New York Presbyterian Hospital, Weill Cornell Medical Center, 525E. 68th St., \\ New York, New York 10021, USA)
}

\begin{abstract}
Analysis of knockout mice suggests that the neurotropininducible secreted polypeptide VGF (non-acronymic) plays an important role in the regulation of energy balance. VGF is synthesized by neurons in the central and peripheral nervous systems (CNS, PNS), as well as in the adult pituitary, adrenal medulla, endocrine cells of the stomach and pancreatic beta cells. Thus VGF, like cholecystokinin, leptin, ghrelin and other peptide hormones that have been shown to regulate feeding and energy expenditure, is synthesized in both the gut and the brain. Although detailed developmental studies of VGF localization in the
\end{abstract}

CNS and PNS have been completed, little is known about the ontogeny of VGF expression in endocrine and neuroendocrine tissues. Here, we report that VGF mRNA is detectable as early as embryonic day 15.5 in the developing rat gastrointestinal and esophageal lumen, pancreas, adrenal, and pituitary, and we further demonstrate that VGF mRNA is synthesized in the gravid rat uterus, together supporting possible functional roles for this polypeptide outside the nervous system and in the enteric plexus.

Journal of Endocrinology (2003) 179, 227-235

\section{Introduction}

VGF was originally identified as a rapidly regulated gene product in nerve growth factor (NGF)-treated PC12 cells (Levi et al. 1985, Cho et al. 1989, Salton et al. 1991). Of particular interest, the VGF polypeptide is highly conserved among several mammalian species, and is stored in large dense core vesicles where it is differentially processed and released from the regulated secretory pathway of both neuronal and endocrine cells (Possenti et al. 1989, 1999, Benson \& Salton 1996). Recent studies of VGF-deficient mice that were generated by gene targeting indicate that VGF plays a crucial role in the control over energy balance (Hahm et al. 1999, 2002). VGF mutant mice are lean, hypermetabolic and hyperactive, and analysis of hypothalamic gene expression indicates that these mice have elevated levels of neuropeptide Y (NPY) and agoutirelated peptide mRNAs, encoding two powerful orexigenic neuropeptides, and decreased pro-opiomelanocortin mRNA that encodes the satiety-inducing peptide alpha-melanocyte stimulating hormone. Consistent with this phenotype, VGF mRNA levels are regulated in the hypothalamic arcuate nucleus in response to fasting (Hahm et al. 1999, 2002), and in the dorsal motor nucleus of the vagus and nucleus tractus solitarius in response to gastrointestinal manipulation (Kanemasa et al. 1995a,b, Hahm et al. 1999, 2002). Since the abnormalities noted in VGF mutant mice extend to low circulating insulin and glucose levels, and VGF is stored and secreted from pancreatic beta cells, it remains possible that central nervous system-, peripheral nervous system- and/or peripherally-synthesized VGF peptides may each function to control energy homeostasis. Recent studies of VGF mutant mice further suggest a role for VGF in the regulation of energy storage in peripheral metabolic tissues that are innervated by the autonomic nervous system. Little, however, is known about VGF expression in extra-neuronal sites in the developing rodent. We therefore examined the ontogeny and distribution of VGF mRNA in non-neural tissues during rat development. We report that VGF is expressed as early as embryonic day 15.5 in several neuroendocrine and endocrine tissues, consistent with a possible functional role for this secreted polypeptide outside the nervous system. 


\section{Materials and methods}

Postnatal or timed-pregnant Sprague-Dawley rats (Charles River Laboratories, Wilmington, MA, USA; Zivic-Miller Laboratories, Allison Park, PA, USA) were killed by $\mathrm{CO}_{2}$ narcosis, and rapidly dissected on ice. The day following the evening of conception was considered embryonic day 0 (E0), and the day of birth postnatal day 0 (P0). Brains, heads, or whole embryos were then embedded in OCT compound (Miles, Elkhart, IN, USA), frozen in 2-methyl-butane on dry ice powder, and stored at $-20{ }^{\circ} \mathrm{C}$ before sectioning. Frozen sections $(10 \mu \mathrm{m})$ were cut on a Bright-Hacker cryostat (Huntingdon, Cambs, UK), thaw-mounted onto Superfrost/Plus slides (Fisher Scientific, Fairlawn, NJ, USA), and stored at $-20{ }^{\circ} \mathrm{C}$ or $-80{ }^{\circ} \mathrm{C}$.

\section{Preparation of $c R N A$ probes and in situ hybridization}

The VGF cRNA and sense strand control probes were transcribed using ${ }^{35}$ S-labeled UTP (New England Nuclear, Boston, MA, USA), Riboprobe System II transcription buffers (Promega, Madison, WI, USA), either T3 or T7 RNA polymerase (Stratagene, La Jolla, CA, USA) and a linearized plasmid construct that was previously described and contains a 304 base pair cDNA fragment corresponding to bases 1592-1896 of the 3' end of the VGF coding region (Salton et al. 1991). Labeled cRNA probes were purified by Sephadex G100 (Pharmacia, Piscataway, NJ, USA) column chromatography, and stored at $-80{ }^{\circ} \mathrm{C}$ in $100 \mathrm{mM}$ dithiothreitol until use.

In situ hybridization was carried out essentially as previously described by Snyder et al. (1998). Briefly, slides were fixed in RNase-free $4 \%$ paraformaldehyde, $50 \mathrm{mM}$ $\mathrm{NaCl}, 100 \mathrm{mM}$ sodium phosphate $(\mathrm{pH} 7 \cdot 2)$ fixative for 2-15 min, rinsed and dehydrated through a graded ethanol series, then rehydrated and incubated in a $0.05 \mathrm{M}$ triethanolamine, $0.026 \mathrm{M}$ acetic acid solution for $2 \mathrm{~min}$. Slides were then acetylated for $10 \mathrm{~min}$, rinsed, and dehydrated. Sections were prehybridized for 1-2 h, hybridized overnight at $50{ }^{\circ} \mathrm{C}$, washed for $30 \mathrm{~min}$ twice, treated with ribonuclease $\mathrm{A}$, then washed several times to a final stringency of $0 \cdot 2 \times \mathrm{SSC}$ at $65-70{ }^{\circ} \mathrm{C}$ for $2 \mathrm{~h}$, as previously detailed (Snyder et al. 1998). In each experiment, the appropriate VGF sense-strand cRNA probe was hybridized to adjacent sections in parallel with antisense probe. After dehydration through a graded ethanol series containing $300 \mathrm{mM}$ ammonium acetate, slides were air dried and exposed to Hyperfilm- $\beta$ max film (Amersham, Arlington Heights, IL, USA) alongside $\left[{ }^{14} \mathrm{C}\right]$ micro-scales (Amersham) for 2 days to 2 weeks. Films were developed and slides were then dipped in a 1:1 mixture of Kodak NTB2 emulsion and HPLC-grade $\mathrm{dH}_{2} \mathrm{O}$ at $42{ }^{\circ} \mathrm{C}$, exposed for 1-4 weeks, then developed. Slides were counterstained with cresyl violet (Eastman Kodak, Rochester, NY, USA), dehydrated, cleared in two changes of Polyclear (D-Limonene; Florida Chemical, Winter Haven, FL, USA), and coverslipped with DPX mountant (Fluka Chemicals, Ronkonkoma, NY, USA).

\section{Image preparation}

Emulsion-dipped sections were visualized on a Stemi SV8 dissecting microscope (Zeiss, Germany) and a Microphot FX microscope (Nikon, Japan), and bright field and dark field photomicrographs were taken using Kodak Ektachrome 160T slide film. Ektachrome slides and film autoradiographs were scanned into a Power Macintosh computer (Apple, Cupertino, CA, USA) using an ARCUS II flatbed scanner and Fotolook software (Agfa, Wilmington, MA, USA). Composite figures were made using Photoshop (Adobe Systems, Mountain View, CA, USA) on a Power Macintosh computer with minimal adjustments to brightness, contrast, and sharpness.

\section{Results}

To characterize the ontogenic expression pattern of the $v g f$ gene, the regional and cellular localization of VGF mRNA was studied using in situ hybridization in rats from embryonic day 11.5 (E11.5) to postnatal day 10 (P10). Specific hybridization was first observed at midgestation in cranial, sympathetic and sensory ganglia (Snyder et al. 1998), after which the distribution broadened throughout the nervous system. Expression in non-neural tissues was first noted at E11.5, not in the embryo proper but rather in the gravid uterus where strong VGF mRNA hybridization in a subpopulation of cells in the uterine wall was noted. At this age, hybridization was also seen between the trophoblast and the maternal decidua (Fig. 1A and B), while at E13.5, VGF mRNA was expressed in a monolayer of cells (Fig. $1 \mathrm{C}$ and D), a pattern that might be expected for intramural postganglionic parasympathetic neurons.

\section{Gastrointestinal, pancreatic and adrenal expression of VGF}

Within the embryo, VGF mRNA was initially detected outside peripheral and central nervous tissues at E15.5, in the primordial myenteric plexus of the stomach (Fig. 2A and B). By E17.5, VGF mRNA expression in the developing stomach and surrounding bowel was more robust (Fig. 2C). A parasagittal section of the E19.5 embryo demonstrated a strong VGF hybridization signal in the esophageal mucosa and developing pancreas, and discrete labeling of the developing myenteric plexus and enteric ganglia in both the esophagus and stomach (Fig. 2D and E). In the developing stomach, VGF hybridization in cells of the non-glandular (non-Gl) mucosa was detected (Fig. $2 \mathrm{~F})$. In addition, VGF mRNA expression in the adrenal gland was also noted as early as E15.5 (Fig. 2G and H). Previous reports demonstrated relatively early expression 

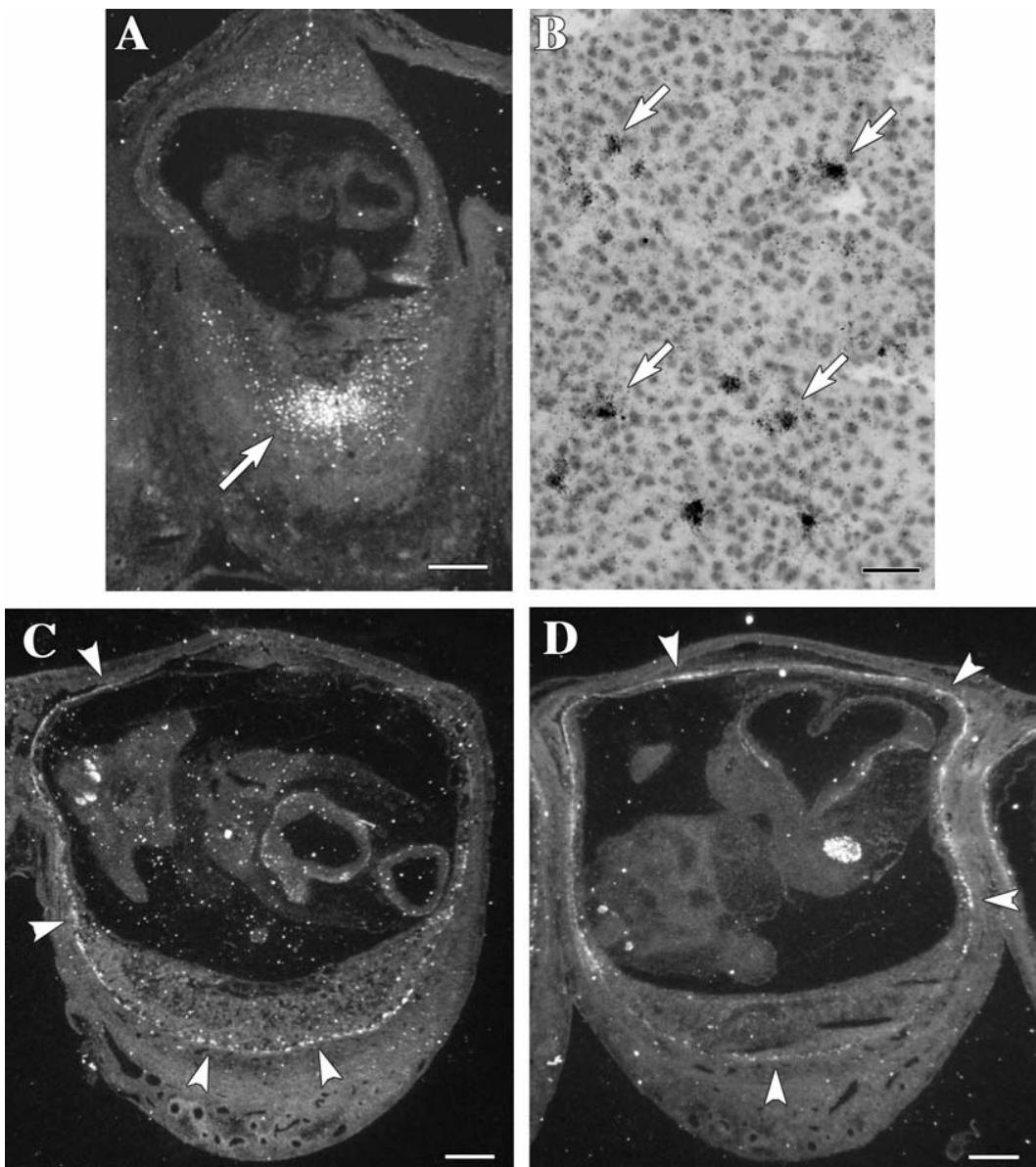

Figure 1 VGF mRNA expression in the gravid rat uterus at E11.5 (A and B) and E13.5 $(C$ and $D)$. Note strong VGF hybridization in a subpopulation of cells in the uterine wall (arrows, A and B) at E11.5, and the development of a monolayer of labeled cells (arrowheads, $C$ and $D$ ) in this region between the trophoblast layer and the maternal component of the decidual reaction at E13.5. Scale bars: A, C and D, $1 \mathrm{~mm} ; \mathrm{B}, 80 \mu \mathrm{m}$.

of VGF mRNA in developing sympathetic and sensory neurons that innervate some of these peripheral targets (Snyder et al. 1998). In the current study, we further noted that cholinergic ganglia that are located in the submandibular gland, adjacent to ducts $\left(\mathrm{I}_{1}\right)$ and acini $\left(\mathrm{I}_{2}\right)$ were also strongly labeled with VGF probes at E19.5 (Fig. 2I).

\section{Pituitary expression of VGF}

The ontogeny of VGF mRNA expression in the pituitary from E15.5 to birth is illustrated in Fig. 3. VGF mRNA was first seen in the developing pars tuberalis (A and $A^{\prime}$ ). By E17.5 (B and $\left.\mathrm{B}^{\prime}\right)$, scattered cells in the pars distalis also displayed strong VGF labeling. This pattern was maintained at E19.5 (C and $\left.\mathrm{C}^{\prime}\right)$. By P0 (D and $\left.\mathrm{D}^{\prime}\right)$, however, expression levels in the pars tuberalis had declined some- what and a low level of labeling was now detectable in the pars intermedia. Coronal sections through the P1 and adult pituitary revealed continued expression of VGF mRNA in the anterior pituitary, and low levels in the intermediate lobe (Fig. 4). No VGF-specific labeling was seen in the pars nervosa at any stage of development studied (Figs 3 and 4).

\section{Discussion}

VGF is expressed in a number of endocrine and neuroendocrine tissues, and is first detectable in the pituitary, adrenal and developing myenteric plexus at E15.5. Later in embryogenesis, expression expands to the pancreas and mucosal lining of the esophagus, stomach and intestine. Consistent with a possible functional role in the gastrointestinal (GI) tract, VGF expression in cholinergic ganglia 

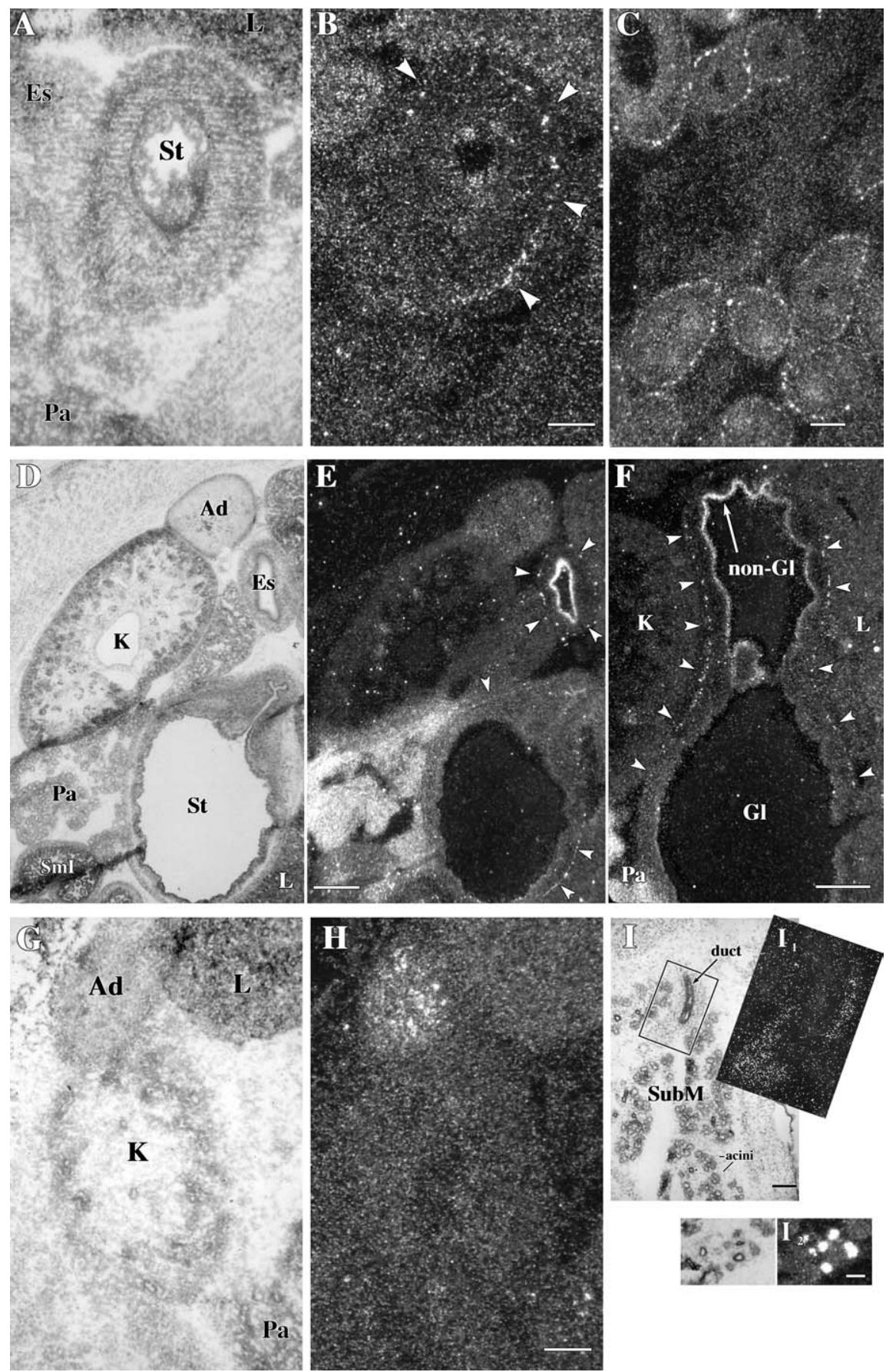

Figure 2 VGF mRNA expression in the developing Gl tract and adrenal of the E15.5, E17.5 and E19.5 rat embryo. In A and B, emulsion autoradiographs of the developing E15.5 stomach (St) and surrounding regions are shown in bright and dark field. Arrowheads highlight VGF mRNA hybridization in the developing myenteric plexus. In C, dark field emulsion autoradiography of the developing stomach and surrounding bowel in an E17.5 embryo is shown. In D and E, abdominal organs of an E19.5 embryo are shown in bright and dark field. Note intense hybridization over cells of the esophageal (Es) lining and the pancreas ( $\mathrm{Pa}$ ). In $\mathrm{F}$, mucosal hybridization in the non-glandular (non-Gl) portion of the stomach of an E19.5 embryo is shown. Arrowheads (E-F) indicate the labeled enteric ganglia. In G and H, the developing kidney $(\mathrm{K})$ and adrenal gland (Ad) and surrounding region are shown in bright and dark field at E15.5. In I, labeling of parasympathetic ganglia adjacent to the submaxillary gland (SubM) duct (boxed region in I corrresponds to dark field autoradiograph in $\mathrm{I}_{1}$ ) is shown. Longer exposure of ganglia adjacent to the SubM acini of another E19.5 embryo is shown in $\mathrm{I}_{2}$. L, liver; Sml, small intestine. Scale bars: B, $200 \mu \mathrm{m}$; C, $250 \mu \mathrm{m} ; \mathrm{E}$ and $\mathrm{F}, 500 \mu \mathrm{m} ; \mathrm{H}, 200 \mu \mathrm{m} ; \mathrm{l}, 200 \mu \mathrm{m} ; \mathrm{I}_{2} 50 \mu \mathrm{m}$. 

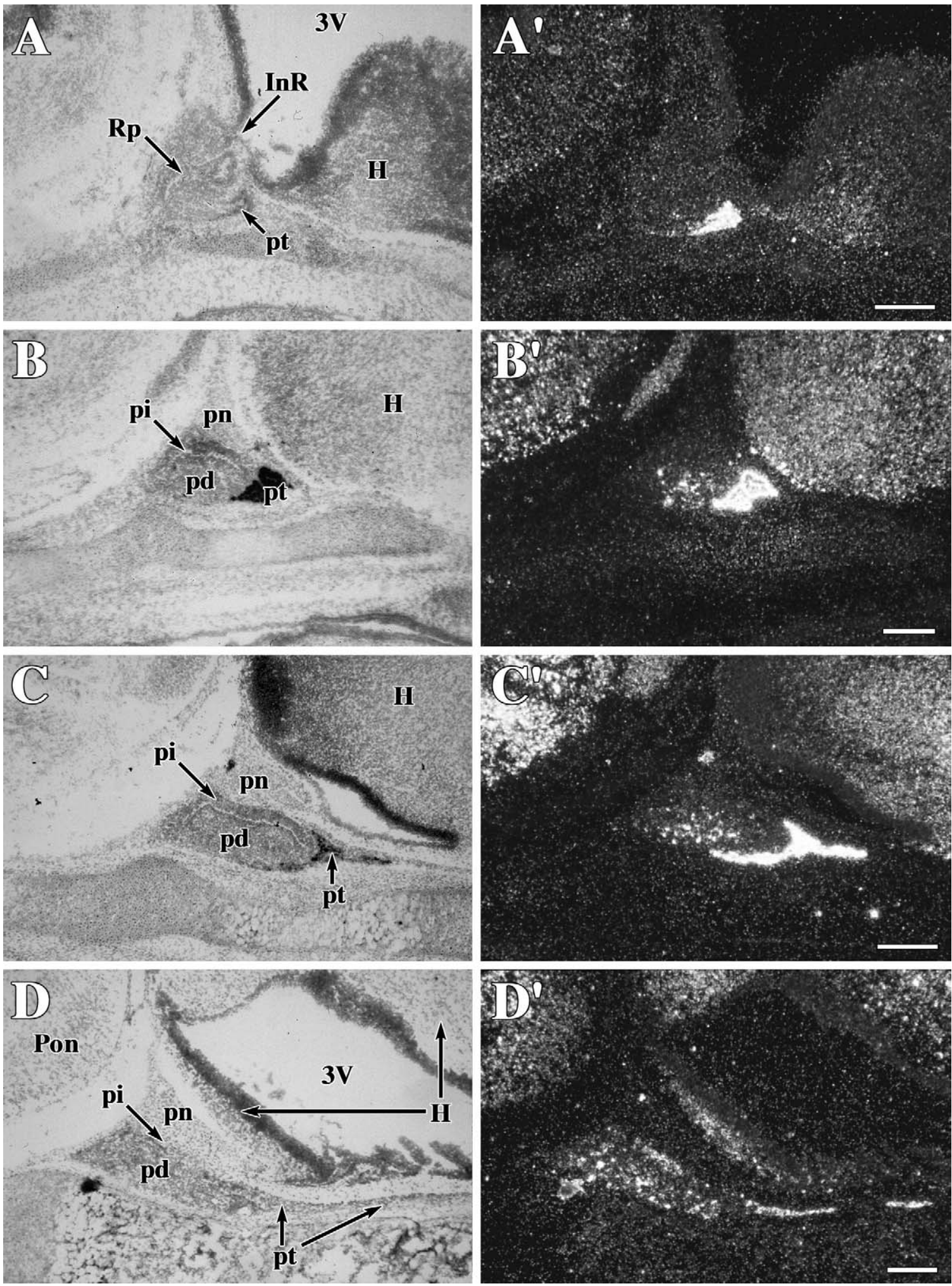

Figure 3 Ontogeny of VGF mRNA expression in parasagittal sections through the rat pituitary gland and surrounding tissue is shown in bright and dark field. (A and A') E15.5; (B and B') E17.5; (C and $\left.C^{\prime}\right)$ E 19.5; (D and D') P0. H, hypothalamus; InR, infundibular recess; pd, pars distalis; pi, pars intermedia; pn, pars nervosa; pt, pars tuberalis; Pon, pontine nucleus, Rp, Rathke's pouch; 3 V, third ventricle. Scale bars, $250 \mu$ m. 

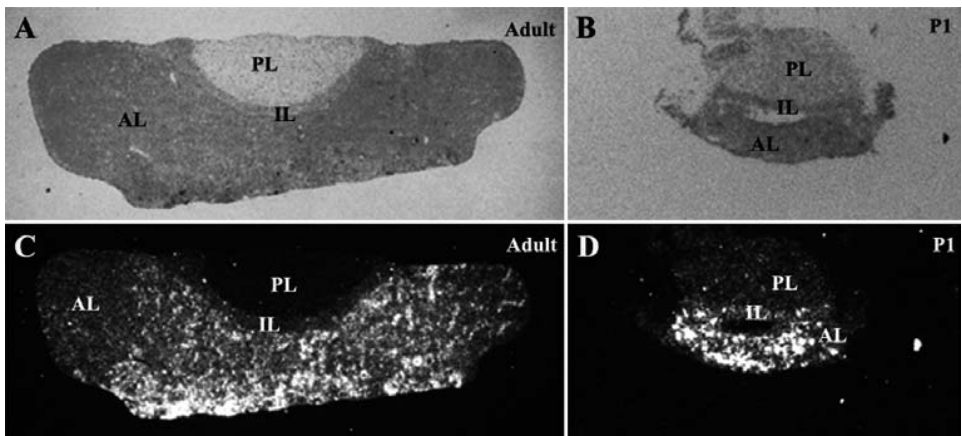

Figure 4 Postnatal VGF expression in coronal sections through the isolated rat pituitary gland. Bright field (A, B) and dark field $(C, D)$ images of adult $(A, C)$ and $\mathrm{P} 1(\mathrm{~B}, \mathrm{D})$ pituitary glands are shown. PL, posterior lobe; IL, intermediate lobe; $\mathrm{AL}$, anterior lobe.

was also noted. Sites of VGF synthesis in both the myenteric plexus of the gut and possibly the intramural postganglionic parasympathetic neurons in the uterus would be consistent with a proposed role for VGF and/or VGF-derived peptides in smooth muscle contraction (A Levi, personal communication). The pattern of expression of VGF mRNA in the decidualized endometrium of the uterus at E11.5 was similar to that previously noted for peptidylglycine $\alpha$-amidating monooxygenase mRNA (Zhang et al. 1997), encoding an enzyme involved in the activation of peptides by amidation. The VGF polypeptide notably has greater than 10 paired basic amino acid clusters, several of which are cleaved to generate VGFderived peptides, one of which is predicted to be amidated (Salton et al. 2000, Trani et al. 2002). Other studies of the adult rat uterus have localized secretoneurin, the 33 amino acid peptide that is cleaved from secretogranin II, in sensory fibers and neurons that are apposed to postganglionic parasympathetic neurons (Collins et al. 2000). Secretogranin II, like VGF and other members of the chromogranin/secretogranin family, is also found in and secreted from large dense core vesicles of neuronal, neuroendocrine and endocrine cells. Thus VGF is expressed in the uterus during pregnancy; it is also of interest to note that female homozygous VGF knockout mice are infertile, although it is unlikely that this is due solely to uterine and/or placental dysfunction (Hahm et al. 1999).

In the developing gut, a similar pattern of distribution to that of VGF in the developing myenteric plexus has been noted for the serotonin $5-\mathrm{HT}_{2 \mathrm{~B}}$ receptor (Fiorica-Howells et al. 2000) and for cholecystokinin (CCK) (Lay et al. 1999). Previous studies demonstrated that VGF mRNA was first detected in migrating neural crest cells and sympathetic and sensory ganglia (Snyder et al. 1998), consistent with our localization of VGF in the enteric innervation of the GI tract since the enteric nervous system is derived from neural crest cells that migrate into the gut. Relatively robust expression of VGF mRNA in the developing mucosal lining of the gut was also noted in the current study. In the adult, several gastric endocrine cell types appear to contain VGF peptides (Ferri et al. 1992; G-L Ferri, personal communication), reminiscent of the distribution of the hormone leptin, a key peripheral regulator of energy balance. Thus, the distribution of VGF in peripheral tissues such as the developing stomach that we noted in this study, as well as in the brain and adult GI tract, is similar to a number of peptides that have been implicated in the control of feeding behavior, facilitation of nutrient uptake and regulation of gastric contractility, including ghrelin and CCK. Of interest, VGF is induced in NPY-containing neurons in the medial arcuate nucleus of the hypothalamus in response to fasting, and, furthermore, VGF mutant mice are lean, hypermetabolic and hyperactive (Hahm et al. 1999). This suggests that VGF may function to decrease metabolic rate, the normal response to starvation, and perhaps to centrally regulate food intake, as do a number of other similarly localized peptide hormones.

In the pituitary, the onset of VGF expression in the pars tuberalis seemed to occur simultaneously throughout, just at the time these cells are differentiating. By E15.5, the cells of the developing pars tuberalis have been shown to have become non-mitotic and to possess a differentiated secretory morphology, making this the earliest differentiating lobe of the adenohypophysis (Stoeckel et al. 1973, 1993). At this time, expression of pituitary cell-type terminal differentiation markers is first noted (reviewed in Dasen \& Rosenfeld 2001). Throughout both the nonmitotic differentiation and proliferative periods, intense in situ hybridization for the glycoprotein hormone $\alpha$-subunit has been described in the pars tuberalis and pars distalis, in a nearly identical pattern to that seen for VGF hybridization except that the $\alpha$-subunit was shown to be expressed in Rathke's pouch as early as E12 (Stoeckel et al. 1993). Immunoreactivity for the adrenal, gonadal and thyroid stimulating hormones of the pars distalis has also been described by E15 in pars tuberalis, one day earlier than similar expression in the pars distalis (Nemeskeri et al. 
Pitx-1 binding elements

(G/A)GATTA(G/T/C)

Putative Pitx-1 binding elements

Human VGF

-666 to -660

GGATTAC

-2302 to -2296
Rat $v g f$

-658 to -652

-836 to -829
TGATTAC

GGATTAA

\section{GATA binding elements} (A/T)GATA(A/G)

Putative GATA binding elements Human VGF

-1061 to -1056

AGATAC

-1027 to -1022

GTATCT

-2237 to -2232

CTATCT

Rat $v g f$

-1061 to -1056

-801 to -796

to

\section{Steroidogenic Factor-1 (SF-1) binding elements \\ TGACCTTG(T/G) \\ CAGCCTTGG mouse 21-hydroxylase (-141 to -133) \\ TGGCCATGT human LH $\beta(-129$ to -121$)$}

Putative Steroidogenic Factor-1 (Sf-1) binding element

Human VGF

-1454 to $-1446 \quad$ TGACCTTGG

Steroidogenic Factor-1 (Sf-1)-like binding elements conserved in rat and human $v g f$ Human VGF

-91 to -83

TCCCCATGA

Rat $v g f$

-545 to -537

-92 to -84

-557 to -549
AGATAC

TTATCA

Figure 5 Elements in the rat and human vgf promoters that are similar to Pitx-1, GATA-2 and SF-1 binding sites. Putative vgf binding sites from the rat (Salton et al. 1991; chromosome 12 WGS supercontig Rn12_330) and human (Canu et al. 1997) sequences are compared with consensus elements for Pitx-1

(Melamed et al. 2002), GATA-2 (Steger et al. 1994), and SF-1 (Halvorson et al. 1996, Catalano et al. 2003).

1988, Japon et al. 1994). In addition, the melatonin receptor, MT1, has been shown to be expressed in the pars tuberalis by E14 (Johnston et al. 2003) as has the transcription factor, pituitary homeobox-1 (Pitx-1), which stimulates the promoter activity of many pituitary-specific genes (Lamonerie et al. 1996, Szeto et al. 1996, Tremblay et al. 1998, Lanctot et al. 1999). Pitx-1 expression is highest in the pars tuberalis and pars distalis of ventral origin, co-localizing with luteinizing hormone beta (LH- $\beta$ ) expression and with the distribution of VGF described here. As a consequence of these striking similarities in distribution, we re-examined the human and rat $v g f$ promoter sequences for putative Pitx-1 binding sites. Two candidate sites resembling the consensus element in each promoter were noted (see Fig. 5). Another lineagespecifying transcription factor that regulates gonadotrope development and function, Egr-1/NGFI-A, has been previously noted to bind the rat $v g f$ promoter (D'Arcangelo et al. 1996) and to induce both LH- $\beta$ (Tremblay \& Drouin 1999) and VGF transcription (D'Arcangelo et al. 1996). Finally, consensus binding elements for factors that are involved in the transactivation of gonadotrope-associated genes, including GATA binding factor 2 and steroidogenic factor-1 (SF-1), were also found in the $v g$ promoter (see Fig. 5). This suggests the possiblity that some of these proteins could form functional complexes with one another (see Dasen \& Rosenfeld 2001), or with additional transcription factors including CREB that 
are critical for VGF regulation in neurons (see Salton et al. 2000). Lastly, the primate pars tuberalis and other lobes of the adenohypophysis express neurotropin and $\mathrm{p} 75^{\mathrm{NTR}}$ immunoreactivity during development and in the adult (Borson et al. 1994), providing a possible link between VGF expression and neurotropin activity in the maturing pituitary.

From E17.5 onward, scattered cells in the pars distalis also displayed strong VGF mRNA expression, and at P0, hybridization could be seen in the pars intermedia. In postnatal and adult coronal sections, VGF mRNA expression was seen scattered throughout the anterior pituitary, while no signal was detected in the posterior pituitary. Immunohistochemical studies have found VGF immunostaining in occasional anterior pituitary lactotropes in adult males, and in gonadotropes and a few lactotropes in adult females, the levels of which vary with the estrous cycle (Ferri et al. 1995). In addition to anterior pituitary endocrine cells, VGF is also found in parvocellular and magnocellular hypothalamic neurons projecting to the median eminence and to the posterior pituitary respectively (Liu et al. 1994, Ferri et al. 1995, Hahm et al. 2002). Our studies further confirm that the C-terminal VGF peptide isolated from the posterior pituitary (Liu et al. 1994) is unlikely to have been synthesized in the posterior pituitary since no VGF mRNA was detected, but rather is most likely transported from the hypothalamus.

\section{Funding}

This work was supported in part by NIH Grants DK57702 and AG10676 (SRJS), DA08622 (JEP), and the American Heart Association (AHA 0350085N) (S R J S).

\section{References}

Benson DL \& Salton SR 1996 Expression and polarization of VGF in developing hippocampal neurons. Brain Research. Developmental Brain Research 96 219-228.

Borson S, Schatteman G, Claude P \& Bothwell M 1994 Neurotrophins in the developing and adult primate adenohypophysis: a new pituitary hormone system? Neuroendocrinology 59 466-476.

Canu N, Possenti R, Rinaldi AM, Trani E \& Levi A 1997 Molecular cloning and characterization of the human VGF promoter region. Journal of Neurochemistry 68 1390-1399.

Catalano S, Pezzi V, Chimento A, Giordano C, Carpino A, Young M, McPhaul MJ \& Ando S 2003 Triiodothyronine decreases the activity of the proximal promoter (PII) of the aromatase gene in the mouse sertoli cell line, TM4. Molecular Endocrinology 17 923-934.

Cho KO, Skarnes WC, Minsk B, Palmieri S, Jackson-Grusby L \& Wagner JA 1989 Nerve growth factor regulates gene expression by several distinct mechanisms. Molecular and Cellular Biology 9 135-143.

Collins JJ, Wilson K, Fischer-Colbrie R \& Papka RE 2000 Distribution and origin of secretoneurin-immunoreactive nerves in the female rat uterus. Neuroscience 95 255-264.

D'Arcangelo G, Habas R, Wang S, Halegoua S \& Salton SR 1996 Activation of codependent transcription factors is required for transcriptional induction of the vgf gene by nerve growth factor and Ras. Molecular and Cellular Biology 16 4621-4631.

Dasen JS \& Rosenfeld MG 2001 Signaling and transcriptional mechanisms in pituitary development. Annual Reviews in Neuroscience 24 327-355.

Ferri GL, Levi A \& Possenti R 1992 A novel neuroendocrine gene product: selective VGF8a gene expression and immuno-localisation of the VGF protein in endocrine and neuronal populations. Brain Research. Molecular Brain Research 13 139-143.

Ferri GL, Gaudio RM, Cossu M, Rinaldi AM, Polak JM, Berger P \& Possenti R 1995 The 'VGF' protein in rat adenohypophysis: sex differences and changes during the estrous cycle and after gonadectomy. Endocrinology 136 2244-2251.

Fiorica-Howells E, Maroteaux L \& Gershon MD 2000 Serotonin and the $5-\mathrm{HT}(2 \mathrm{~B})$ receptor in the development of enteric neurons. Journal of Neuroscience 20 294-305.

Hahm S, Mizuno TM, Wu TJ, Wisor JP, Priest CA, Kozak CA, Boozer CN, Peng B, McEvoy RC, Good P et al. 1999 Targeted deletion of the Vgf gene indicates that the encoded secretory peptide precursor plays a novel role in the regulation of energy balance. Neuron 23 537-548.

Hahm S, Fekete C, Mizuno TM, Windsor J, Yan H, Boozer CN, Lee C, Elmquist JK, Lechan RM, Mobbs CV \& Salton SR 2002 VGF is required for obesity induced by diet, gold thioglucose treatment and agouti, and is differentially regulated in POMC- and NPY-containing arcuate neurons in response to fasting. Journal of Neuroscience 22 6929-6938.

Halvorson L M, Kaiser UB \& Chin WW 1996 Stimulation of luteinizing hormone beta gene promoter activity by the orphan nuclear receptor, steroidogenic factor-1. Journal of Biological Chemistry 271 6645-6650.

Japon MA, Rubinstein M \& Low MJ 1994 In situ hybridization analysis of anterior pituitary hormone gene expression during fetal mouse development. Journal of Histochemistry and Cytochemistry 42 $1117-1125$.

Johnston JD, Messager S, Ebling FJ, Williams LM, Barrett P \& Hazlerigg DG 2003 Gonadotrophin-releasing hormone drives melatonin receptor down-regulation in the developing pituitary gland. PNAS 100 2831-2835.

Kanemasa K, Okamura H, Kodama T \& Ibata Y 1995a Induction of VGF mRNA in neurons of the rat nucleus tractus solitarius and the dorsal motor nucleus of vagus in duodenal ulceration by cysteamine. Brain Research. Molecular Brain Research 32 55-62.

Kanemasa K, Okamura H, Kodama T, Kashima K \& Ibata Y $1995 b$ Time course of the induction of VGF mRNA in the dorsal vagal complex in rats with cysteamine-induced peptic ulcers. Brain Research. Molecular Brain Research 34 309-314.

Lamonerie T, Tremblay JJ, Lanctot C, Therrien M, Gauthier Y \& Drouin J 1996 Ptx1, a bicoid-related homeo box transcription factor involved in transcription of the pro-opiomelanocortin gene. Genes and Development 10 1284-1295.

Lanctot C, Gauthier Y \& Drouin J 1999 Pituitary homeobox 1 (Ptx1) is differentially expressed during pituitary development. Endocrinology 140 1416-1422.

Lay JM, Gillespie PJ \& Samuelson LC 1999 Murine prenatal expression of cholecystokinin in neural crest, enteric neurons, and enteroendocrine cells. Developmental Dynamics 216 190-200.

Levi A, Eldridge JD \& Paterson BM 1985 Molecular cloning of a gene sequence regulated by nerve growth factor. Science 229 393-395.

Liu JW, Andrews PC, Mershon JL, Yan C, Allen DL \& Ben-Jonathan N 1994 Peptide V: a VGF-derived neuropeptide purified from bovine posterior pituitary. Endocrinology 135 2742-2748.

Melamed P, Koh M, Preklathan P, Bei L \& Hew C 2002 Multiple mechanisms for Pitx-1 transactivation of a luteinizing hormone beta subunit gene. Journal of Biological Chemistry 277 26200-26207.

Nemeskeri A, Setalo G \& Halasz B 1988 Ontogenesis of the three parts of the fetal rat adenohypophysis. A detailed immunohistochemical analysis. Neuroendocrinology 48 534-543. 
Possenti R, Eldridge JD, Paterson BM, Grasso A \& Levi A 1989 A protein induced by NGF in PC12 cells is stored in secretory vesicles and released through the regulated pathway. EMBO Journal 8 2217-2223.

Possenti R, Rinaldi AM, Ferri GL, Borboni P, Trani E \& Levi A 1999 Expression, processing, and secretion of the neuroendocrine VGF peptides by INS-1 cells. Endocrinology 140 3727-3735.

Salton SR, Fischberg DJ \& Dong KW 1991 Structure of the gene encoding VGF, a nervous system-specific mRNA that is rapidly and selectively induced by nerve growth factor in PC12 cells. Molecular and Cellular Biology 11 2335-2349.

Salton SR, Ferri GL, Hahm S, Snyder SE, Wilson AJ, Possenti R \& Levi A 2000 VGF: a novel role for this neuronal and neuroendocrine polypeptide in the regulation of energy balance. Frontiers in Neuroendocrinology 21 199-219.

Snyder SE, Pintar JE \& Salton SR 1998 Developmental expression of VGF mRNA in the prenatal and postnatal rat. Journal of Comparative Neurology 394 64-90.

Steger DJ, Hecht JH \& Mellon PL 1994 GATA-binding proteins regulate the human gonadotropin alpha-subunit gene in the placenta and pituitary gland. Molecular and Cellular Biology 14 $5592-5602$

Stoeckel ME, Porte A, Hindelang-Gertner C \& Dellmann HD 1973 A light and electron microscopic study of the pre- and postnatal development and secretory differentiation of the pars tuberalis of the rat hypophysis. Zeitschrift fur Zellforschung und Mikroskopische Anatomie 142 347-365.

Stoeckel ME, Hindelang C, Klein MJ, Poissonnier M \& Felix JM 1993 Early expression of the glycoprotein hormone alpha-subunit in the pars tuberalis of the rat pituitary gland during ontogenesis. Neuroendocrinology 58 616-624.

Szeto DP, Ryan AK, O’Connell SM \& Rosenfeld MG 1996 P-OTX: a PIT-1-interacting homeodomain factor expressed during anterior pituitary gland development. PNAS 93 7706-7710.

Trani E, Giorgi A, Canu N, Amadoro G, Rinaldi AM, Halban PA, Ferri GL, Possenti R, Schinina ME \& Levi A 2002 Isolation and characterization of VGF peptides in rat brain. Role of PC1/3 and PC2 in the maturation of VGF precursor. Journal of Neurochemistry 81 565-574.

Tremblay JJ \& Drouin J 1999 Egr-1 is a downstream effector of GnRH and synergizes by direct interaction with Ptx1 and SF-1 to enhance luteinizing hormone beta gene transcription. Molecular and Cellular Biology 19 2567-2576.

Tremblay JJ, Lanctot C \& Drouin J 1998 The pan-pituitary activator of transcription, Ptx1 (pituitary homeobox 1), acts in synergy with SF-1 and Pit1 and is an upstream regulator of the Lim-homeodomain gene Lim3/Lhx3. Molecular Endocrinology 12 428-441.

Zhang J, Zheng M, Eipper BA \& Pintar JE 1997 Embryonic and uterine expression patterns of peptidylglycine alpha-amidating monooxygenase transcripts suggest a widespread role for amidated peptides in development. Developmental Biology 192 375-391.

Received 23 May 2003

Accepted 5 August 2003

Made available online as an

Accepted Preprint 11 August 2003 